\title{
Desain Antar Muka Aplikasi Informasi Terdokumentasi ISO 9001:2015
}

\section{Interface Design Of ISO 9001: 2015 Documented Information Application System}

\author{
Aneke Rintiasti \\ Balai Riset dan Standardisasi Industri Surabaya \\ Kementerian Perindustrian \\ Surabaya, Indonesia \\ anekerintiasti@gmail.com
}

\begin{abstract}
Abtsrak - Implementasi dan sertifikasi sistem manajemen mutu (Quality Management System / QMS), terutama untuk usaha kecil dan menengah, melibatkan, volume dokumen dan catatan yang cukup besar yang berkaitan dengan jumlah dan pekerjaan karyawannya. Makalah ini membahas solusi organisasi dan pemantauan yang efisien, dengan fokus pada pengelolaan informasi terdokumentasi, yang bisa mendukung organisasi dalam menerapkan sistem manajemen mutu SNI ISO 9001:2015 yang efektif dan efisien pada perusahaan kecil dengan menghadirkan solusi perangkat lunak.
\end{abstract}

Kata Kunci-sistem manajemen mutu, antar muka, informasi terdokumentasi, ISO 9001:2015

\begin{abstract}
Quality Management System (QMS) implementation and certification, especially for small and medium enterprise, involves, quite large volume of documents and record relating to the number and duties employees.The paper deals with efficient organizational and monitoring solution, focusing on documented information management, which can support organizations in implementing an effective and efficient SNI ISO 9001: 2015 quality management system for small companies by delivering software solutions."
\end{abstract}

Keywords - quality management system, interface, documented information, ISO 9001: 2015

\section{PENDAHULUAN}

Peran penting implementasi sistem manajemen mutu telah diakui oleh perusahaan manufaktur makanan $[1,2]$. Hal ini disebabkan tingginya kesadaran pelanggan akan pentingnya kualitas produk makanan dan keamanan [1]. Perusahaan makanan yang menghasilkan produk berkualitas dan aman akan bertahan dan bahkan memenangkan persaingan [1].

ISO 9001 adalah standar internasional sistem manajemen mutu [3]. Standar tersebut menjelaskan persyaratan sistem manajemen mutu yang perlu diimplementasikan secara konsisten sehingga perusahaan dapat menghasilkan produk sesuai dengan kebutuhan pelanggan, mencapai kepuasan pelanggan, dan mencapai peningkatan berkesinambungan terhadap efektivitas sistem manajemen mutu mereka $[3,4,5]$. Selanjutnya, persyaratan ISO 9001 merupakan praktik terbaik sistem manajemen mutu [4]. Dengan demikian, perusahaan manufaktur makanan yang menerapkan ISO 9001 diharapkan memperoleh hasil yang signifikan $[5,6,7]$.

ISO 9001: 2015, yang diterbitkan pada bulan September 2015, menggabungkan Sistem Manajemen Mutu pendekatan berbasis risiko [8].

Memang penerapan dan sertifikasi QMS terutama untuk usaha kecil dan menengah, melibatkan satu volume, kadang cukup besar, dokumen dan catatan yang berkaitan dengan jumlah tugas karyawan, namun dengan menemukan solusi organisasi dan pemantauan yang efektif, sistem mungkin akan membaik. Karena jumlah pegawai yang kecil, yang berarti tanggung jawab dan fungsi kumulatif, terutama di perusahaan manufaktur, mengurangi jumlah prosedur, seiring dengan pengelolaan dokumen menggunakan teknologi informasi, dapat menjadi solusi untuk mempermudah kualitas sistem manajemen guna meningkatkan efektivitas. [9]

Meskipun terdapat metodologi yang berbeda untuk menerapkan sistem manajemen mutu, namun semua sepakat pentingnya penanganan dokumen yang tepat untuk memastikan keberhasilannya,selain itu tidak satupun yang menjelaskan secara rinci bagaimana merancang dan menerapkan sistem manajemen dokumen yang sesuai untuk menangani dokumentasi, atau mendefinisikan proses dokumen yang terkait.[10]

Tujuan penelitian ini adalah mendapatkan arsistektur system informasi ISO 9001:2015 dengan ruang lingkup informasi terdokumentasi dan mendapatkan desain antar muka sistem informasi ISO 9001:2015 dengan ruang lingkup informasi terdokumentasi. 
Manfaat dari penelitian ini adalah desain sistem informasi yang memberikan kemudahan dalam pengelolaan informasi terdokumentasi pada SNI ISO 9001:2015.

Penelitian sebelumnya sudah dilakukan oleh pengembangan sistem manajemen Mutu hybrid untuk perusahaan kontruksi [11], analisa manajemen terintegrasi pada mutu, lingkungan dan keselamatan pada proyek industry[8]. Metode penyusunan system manajemen dokumen yang optimal diajukan pada penelitian [10]. Penyederhanaan model sistem manajemen mutu khususnya pada produk tidak sesuai dan ketertelusuran dijelaskan pada penelitian [9]. Namun dari beberapa penelitian tersebut belum ada yang membahas tentang informasi terdokumentasi pada ISO 9001:2015.

\section{BAHAN DAN METODA}

Sistem pengelolaan dokumen berguna karena kelebihan yang ditawarkan: "mengurangi waktu untuk persetujuan dan pengendalian dokumen, transparansi kerja departemen, meningkatkan efisiensi / efektivitas transfer informasi internal dan juga kemungkinan mengamankannya, pengisian elektronik, penyimpanan dan informasi. Masalah yang muncul, adalah tersedianya sumber daya yang dibutuhkan untuk mengembangkan pengelolaan dokumen semacam itu yang melibatkan pembelian komputer dan program perangkat lunak yang ada di lapangan. Investasi perangkat keras masingmasing komputer lebih terjangkau daripada software, yang umumnya cukup mahal [9], namun dengan jasa layanan sistem informasi online maka bisa menghemat waktu, uang tapi juga kepuasan kerja dengan menyederhanakan langkah yang dibutuhkan oleh prosedur yang dipersyaratkan oleh SNI ISO 9001:2015. Gambar 1 menunjukkan metode penelitian.

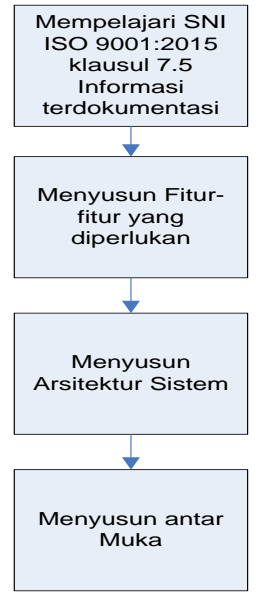

Gambar 1. Metode Penelitian
Bahan yang digunakan antara lain :

Standar yang digunakan : SNI ISO 9001:2015, Alat bantu : Visio

Pada SNI ISO 9001:2015 Klausul 7.5 informasi terdokumentasi bagian 7.5.1 menyebutkan bahwa "Sistem Manajemen Mutu Organisasi harus mencakup: a) Informasi terdokumentasi yang diperlukan oleh Standar ini." Informasi terdokumentasi yang diperlukan klausul 4 sampai klausul 7 dapat dilihat pada table 1. Informasi Terdokumentasi

\section{TABEL I. INFORMASI TERDOKUMENTASI}

\begin{tabular}{|c|c|c|}
\hline \multicolumn{3}{|c|}{ Informasi Terdokumentasi } \\
\hline \multicolumn{2}{|c|}{ Klausul } & \\
\hline $\begin{array}{l}4 \quad \text { Konteks } \\
\text { organisasi }\end{array}$ & 4.3 & $\begin{array}{l}\text { Lingkup sistem manajemen mutu } \\
\text { organisasi harus tersedia dan } \\
\text { dipelihara sebagai informasi } \\
\text { terdokumentasi }\end{array}$ \\
\hline & 4.4 .2 & $\begin{array}{l}\text { Sejauh yang diperlukan, } \\
\text { organisasi harus : } \\
\text { a) Memelihara informasi } \\
\text { terdokumentasi yang } \\
\text { mendukung operasi dari } \\
\text { prosesnya } \\
\text { b) Menyimpan informasi } \\
\text { terdokumentasi untuk } \\
\text { mempunyai keyakinan } \\
\text { bahwa proses yang } \\
\text { dilakukan sesuai rencana }\end{array}$ \\
\hline 5 & 5.2 .2 & $\begin{array}{l}\text { Kebijakan mutu harus: } \\
\text { a) tersedia dan dipelihara sebagai } \\
\text { informasi } \\
\text { terdokumentasi; }\end{array}$ \\
\hline 6 & 6.2 .1 & $\begin{array}{l}\text { Organisasi harus memelihara } \\
\text { informasi terdokumentasi dari } \\
\text { sasaran mutu }\end{array}$ \\
\hline 7 & $\begin{array}{l}\text { 7.1.5 Pemantauan dan } \\
\text { pengukuran } \\
\text { sumber daya } \\
\text { 7,1.5.1 Umum }\end{array}$ & $\begin{array}{l}\text { Organisasi harus menyimpan } \\
\text { informasi terdokumentasi yang } \\
\text { sesuai sebagai bukti kesesuaian } \\
\text { dari tujuan pemantauan dan } \\
\text { pengukuran sumber daya }\end{array}$ \\
\hline & 7.1 .5 .2 & $\begin{array}{l}\text { Bila tidak ada standar, dasar untuk } \\
\text { kalibrasi atau verifikasi harus } \\
\text { disimpan sebagai informasi } \\
\text { terdokumentasi }\end{array}$ \\
\hline & 7.2 kompetensi & $\begin{array}{l}\text { Menyimpan informasi } \\
\text { terdokumentasi yang sesuai } \\
\text { sebagai bukti kompetensi }\end{array}$ \\
\hline
\end{tabular}

Sedangkan pada klausul 7.5.1 bagian b) informasi terdokumentasi yang ditentukan oleh organisasi yang perlu untuk keefektifan sistem manajemen mutu.

Pada klausul 7.5.2 Membuat dan Mutakhirkan disebutkan bahwa "ketika membuat dan memutakhirkan informasi terdokumentasi, organisasi harus memastikan kesesuaian:

1. Identifikasi dan deskripsi (misal judul, tanggal, penulis atau nomer referensi) 
2. Format (missal bahasa, edisi piranti lunak, grafik) dan media (kertas, elektronik)

3. Tinjauan dan persetujuan untuk kecukupan dan kesesuaian"

Pada klausul 7.5.3 Pengendalian informasi terdokumentasi bagian 7.5.3.1 menyebutkan informasi terdokumentasi yang diperlukan oleh standar ini harus dikendalikan untuk memastikan:

a) Ketersediaan dan kesesuaian untuk digunakan, kapan, dimana, jika diperlukan

b) Dilindungi secara cukup (missal kehilangan kerahasiaannya, penggunaan yang tidak sesuai atau kehilangan integritas

Sedangkan pada bagian 7.5.3.2 untuk mengendalikan informasi terdokumentasi, organisasi harus menangani kegiatan berikut ini, jika berlaku :

a) distribusi, akses, pengambilan dan penggunaan

b) penyimpanan dan penjagaan, termasuk penjagaan terhadap kemudahan untuk membaca

c) pengendalian perubahan (missal pengendalian versi)

d) masa simpan dan pembuangan

Informasi terdokumentasi yang berasal dari eksternal ditentukan oleh organisasi untuk keperluan perencanan dan operasi sistem manajemen mutu harus diidentifikasi sesuai dan dikendalikan.

\section{HASIL DAN PEMBAHASAN}

Pada Gambar 2 dapat dilihat fitur sistem informasi (Informasi Terdokumentasi). Fitur-fitur tersebut merupakan fungsi-fungsi utama yang disediakan oleh system informasi berdasarkan persayaratan pada klausul 7.5 SNI ISO 9001:2015

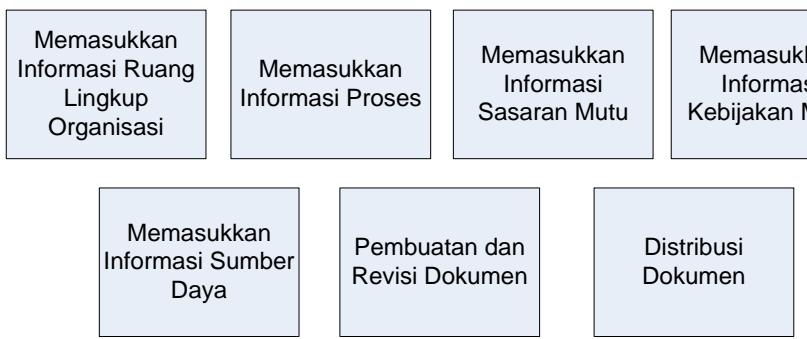

Gambar 2. Fitur Sistem Informasi (Informasi Terdokumentasi)

Sistem Informasi ini dapat diakses oleh organisasi (perusahaan manufaktur) menggunakan koneksi internet. Server aplikasi diletakkan di Baristand Industri Surabaya dan aplikasi berbasis website. Arsitektur Sistem Informasi Manajemen Mutu ISO 9001:2015 dapat dilihat pada Gambar 3.

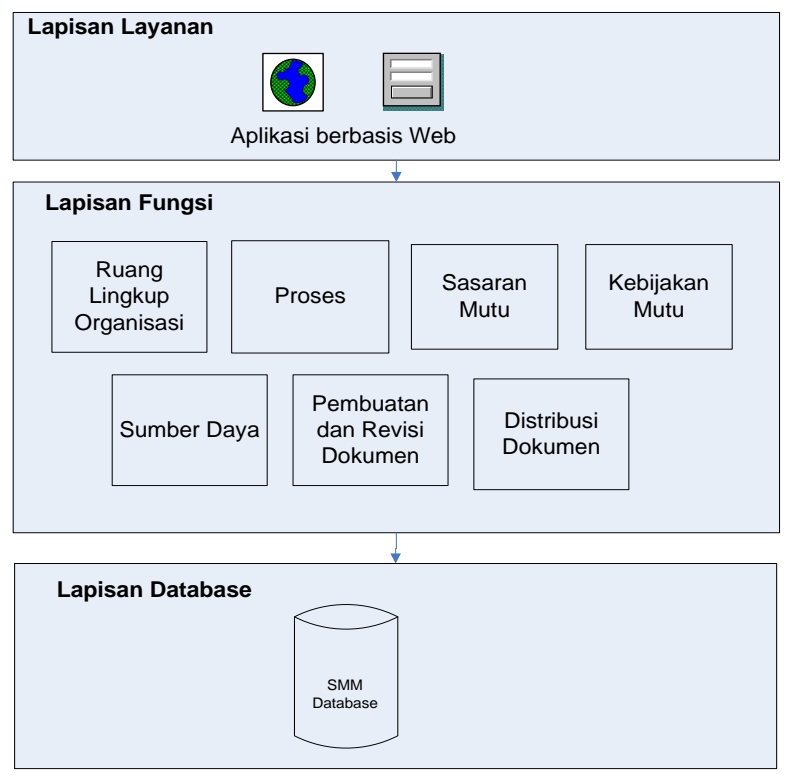

Gambar 3. Arsitektur Sistem Informasi (Informasi Terdokumentasi)

Pengguna dari sistem informasi informasi terdokumentasi ini adalah pengendali dokumen dan penanggung jawab perusahaan. Hal ini dapat dilihat pada Gambar 4.

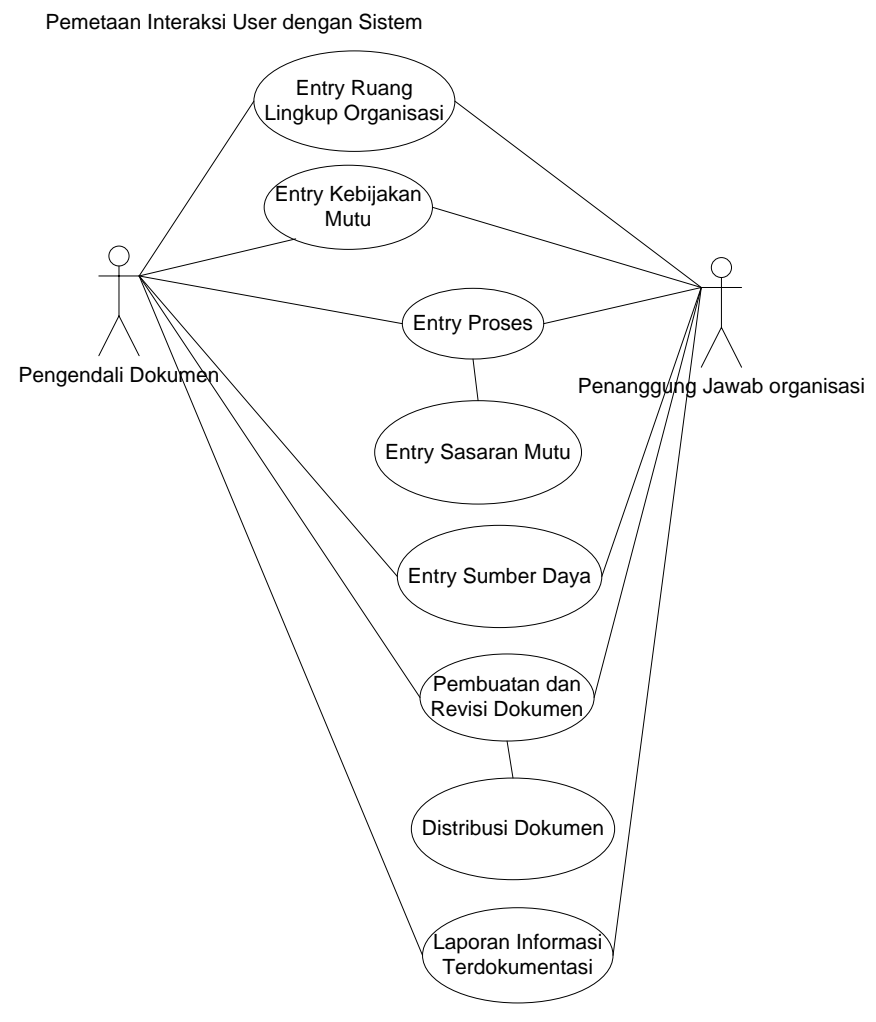

Gambar 4. Pemetaan Interaksi User dengan Sistem 
Setelah mendapatkan fitur, arsitektur dan pemetaan interaksi maka langkah selanjutnya adalah menyusun desain antar muka.

Berikut ini ada desain antarmuka untuk klausul 7.5.1 SNI ISO 9001:2015. Gambar 5 Desain Antar muka Form Lingkup Sistem Manajemen Mutu adalah desain antar muka yang terkait dengan klausul 4.3.

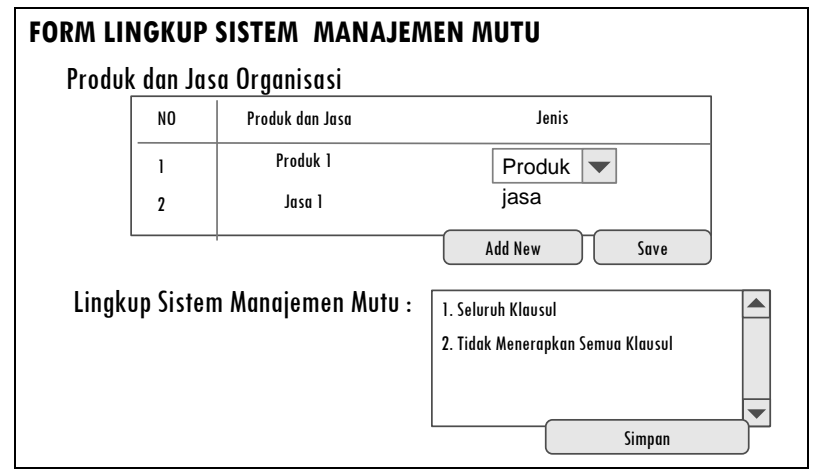

Gambar 5. Desain Antar muka Form Lingkup Sistem Manajemen Mutu

Penjelasan antar muka Gambar 5 dapat dilihat pada Tabel 2 terkait nama komponen, Tujuan / Deskripsi, Tipe dan Editable [13].

TABEL II. DESKRIPSI KOMPONEN PADA FORM RUANG LINGKUP SISTEM MANAJEMEN MUTU PADA ORGANISASI

\begin{tabular}{|c|c|c|c|c|}
\hline No & $\begin{array}{l}\text { Nama } \\
\text { Komponen }\end{array}$ & $\begin{array}{l}\text { Tujuan / } \\
\text { Deskripsi }\end{array}$ & Tipe & $\begin{array}{l}\text { Edit } \\
\text { able }\end{array}$ \\
\hline 1 & $\begin{array}{l}\text { Produk dan } \\
\text { Jasa }\end{array}$ & $\begin{array}{lr}\text { Mempermudah } & \\
\text { pengguna } & \text { dalam } \\
\text { menyimpan } & \text { data } \\
\text { produk dan jasa yang } \\
\text { dihasilkan } \\
\text { perusahaan. Jumlah } \\
\text { produk dan jasa yang } \\
\text { disimpan bisa lebih dari } \\
\text { satu data. }\end{array}$ & $\begin{array}{l}\text { Drop } \\
\text { Down } \\
\text { List }\end{array}$ & $\mathrm{Ya}$ \\
\hline 2 & $\begin{array}{l}\text { Lingkup } \\
\text { Sistem } \\
\text { Manajemen } \\
\text { Mutu }\end{array}$ & $\begin{array}{lr}\text { Mempermudah } & \\
\text { pengguna } & \text { dalam } \\
\text { menyimpan } & \text { klausul } \\
\text { yang diterapkan } & \text { apaka } \\
\text { keseluruhan } & \text { atau } \\
\text { sebagian } & \\
\end{array}$ & $\begin{array}{l}\text { Drop } \\
\text { Down } \\
\text { List }\end{array}$ & Ya \\
\hline
\end{tabular}

Gambar 6 adalah desain antar muka yang terkait dengan klausul 4.4.2 dimana setiap proses dimasukkan informasi yang dipersyaratkan SNI ISO 9001:2015 dan terdapat fasilitas mengunggah dokumen.

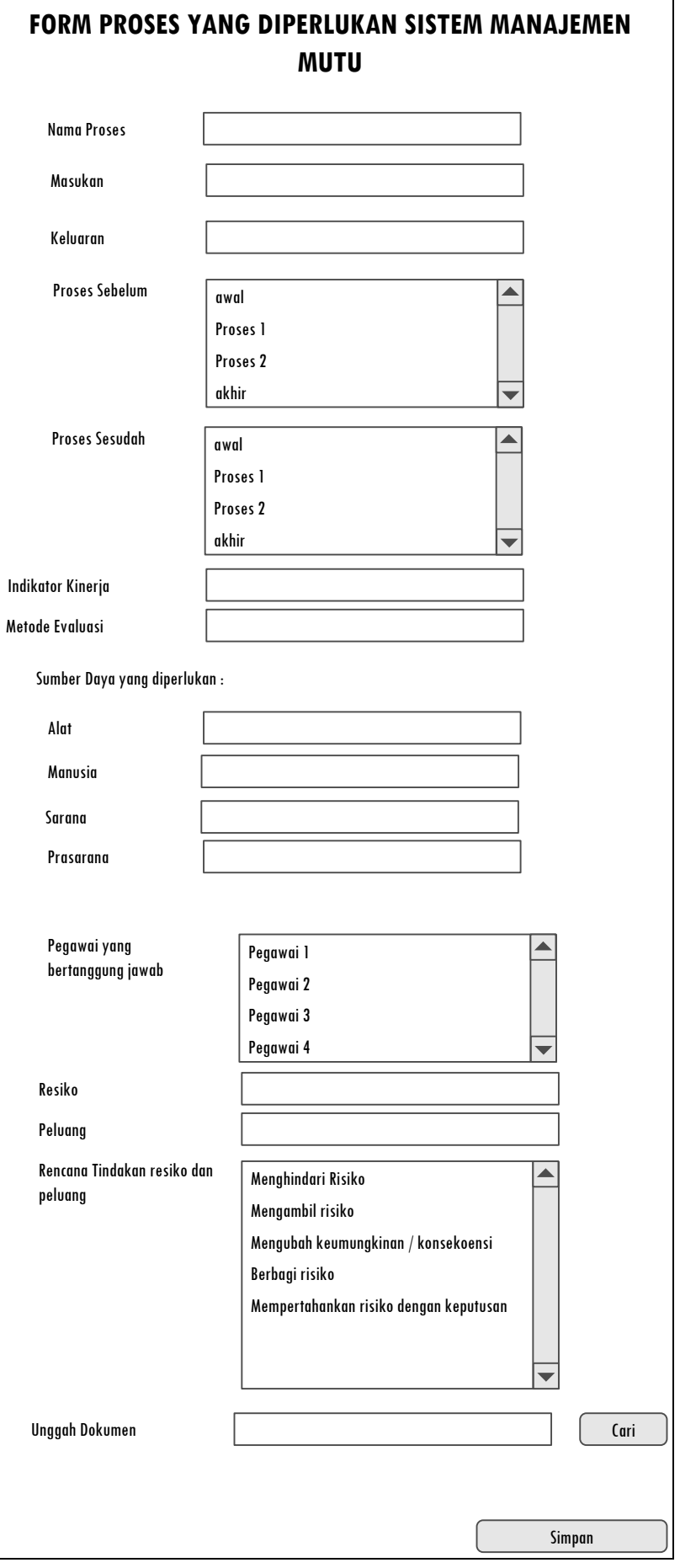

Gambar 6. Desain Antar muka Form Proses yang diperlukan Sistem Manajemen Mutu

Penjelasan antar muka Gambar 6 dapat dilihat pada Tabel 3 terkait nama komponen, tujuan / deskripsi, tipe dan editable [13]. 
TABEL III. DESKRIPSI KOMPONEN PADA FORM PROSES YANG DIPERLUKAN BAGI SISTEM MANAJEMEN MUTU

\begin{tabular}{|c|c|c|c|c|}
\hline No & $\begin{array}{l}\text { Nama } \\
\text { Komponen }\end{array}$ & $\begin{array}{l}\text { Tujuan / } \\
\text { Deskripsi }\end{array}$ & Tipe & $\begin{array}{l}\text { Edita } \\
\text { ble }\end{array}$ \\
\hline 1 & Nama Proses & $\begin{array}{l}\text { Membantu pengguna untuk } \\
\text { menyimpan data proses - proses } \\
\text { yang diperlukan dalam } \\
\text { menghasilkan produk dan jasa }\end{array}$ & textarea & $\mathrm{Ya}$ \\
\hline 2 & Masukan & $\begin{array}{l}\text { Membantu pengguna untuk } \\
\text { menyimpan masukan proses } \\
\text { yang diperlukan oleh proses } \\
\text { tersebut }\end{array}$ & textarea & Ya \\
\hline 3 & Keluaran & $\begin{array}{l}\text { Membantu pengguna untuk } \\
\text { menyimpan keluaran dari proses } \\
\text { tersebut }\end{array}$ & textarea & Ya \\
\hline 4 & $\begin{array}{l}\text { Proses } \\
\text { Sebelum }\end{array}$ & $\begin{array}{l}\text { Membantu pengguna untuk } \\
\text { menyimpan proses yang harus } \\
\text { dilakukan sebelumnya }\end{array}$ & $\begin{array}{l}\text { Drop } \\
\text { down list }\end{array}$ & Ya \\
\hline 5 & $\begin{array}{l}\text { Proses } \\
\text { Sesudah }\end{array}$ & $\begin{array}{l}\text { Membantu pengguna dalam } \\
\text { menyimpan proses yang harus } \\
\text { dilakukan setelahnya }\end{array}$ & $\begin{array}{l}\text { Drop } \\
\text { down list }\end{array}$ & Ya \\
\hline 6 & $\begin{array}{l}\text { Indikator } \\
\text { Kinerja }\end{array}$ & $\begin{array}{l}\text { Membantu pengguna dalam } \\
\text { menyimpan indikator kinerja } \\
\text { sebagai KPI dari proses tersebut }\end{array}$ & textarea & $\mathrm{Ya}$ \\
\hline 7 & $\begin{array}{l}\text { Metode } \\
\text { Evaluasi }\end{array}$ & $\begin{array}{l}\text { Membantu pengguna dalam } \\
\text { menyimpan metode evaluasi } \\
\text { yang akan digunakan untuk } \\
\text { mengevaluasi kinerja proses } \\
\text { tersebut }\end{array}$ & textarea & Ya \\
\hline 8 & $\begin{array}{l}\text { Sumber } \\
\text { Daya yang } \\
\text { diperlukan : } \\
\text { Alat }\end{array}$ & $\begin{array}{l}\text { Membantu pengguna untuk } \\
\text { menyimpan sumber daya alat } \\
\text { yang diperlukan untuk } \\
\text { menjalankan proses tersebut }\end{array}$ & textarea & $\mathrm{Ya}$ \\
\hline 9 & Manusia & $\begin{array}{l}\text { Membantu pengguna untuk } \\
\text { menyimpan sumber daya } \\
\text { manusia yang dibutuhkan dalam } \\
\text { menjalankan proses tersebut }\end{array}$ & textarea & Ya \\
\hline 10 & Sarana & $\begin{array}{l}\text { Membantu pengguna untuk } \\
\text { menyimpan sarana yang } \\
\text { diperlukan dalam proses tersebut }\end{array}$ & textarea & $\mathrm{Ya}$ \\
\hline 11 & Prasarana & $\begin{array}{l}\text { Membantu pengguna untuk } \\
\text { menyimpan prasarana yang } \\
\text { diperlukan dalam proses tersebut }\end{array}$ & textarea & Ya \\
\hline 12 & $\begin{array}{l}\text { Pegawai } \\
\text { yang } \\
\text { Bertanggung } \\
\text { Jawab }\end{array}$ & $\begin{array}{l}\text { Membantu pengguna dalam } \\
\text { menyimpan orang yang } \\
\text { bertanggung jawab dalam proses } \\
\text { tersebut }\end{array}$ & $\begin{array}{l}\text { Drop } \\
\text { down list }\end{array}$ & Ya \\
\hline 13 & Resiko & $\begin{array}{l}\text { Membantu pengguna dalam } \\
\text { mengidentifikasi resiko yang } \\
\text { akan timbul dalam proses } \\
\text { tersebut }\end{array}$ & textarea & Ya \\
\hline 14 & Peluang & $\begin{array}{l}\text { Membantu pengguna dalam } \\
\text { melihat peluang yang timbul } \\
\text { dalam proses tersebut }\end{array}$ & textarea & $\mathrm{Ya}$ \\
\hline 15 & $\begin{array}{l}\text { Rencana } \\
\text { Tindakan } \\
\text { Resiko dan } \\
\text { Peluang } \\
\end{array}$ & $\begin{array}{l}\text { Membantu pengguna dalam } \\
\text { merencanakan tindakan terhadap } \\
\text { resiko ataupun peluang dalam } \\
\text { proses tersebut }\end{array}$ & $\begin{array}{l}\text { Drop } \\
\text { down list }\end{array}$ & Ya \\
\hline 16 & $\begin{array}{l}\text { Unggah } \\
\text { Dokumen }\end{array}$ & $\begin{array}{l}\text { Membantu pengguna dalam } \\
\text { mengunggah dokumen proses } \\
\text { ataupun dokumen pendukung } \\
\text { proses }\end{array}$ & tombol & $\mathrm{Ya}$ \\
\hline
\end{tabular}

Gambar 7 adalah desain antar muka yang terkait dengan klausul 5.2.2 dimana kebijakan mutu dicatat sebagai informasi terdokumentasi.

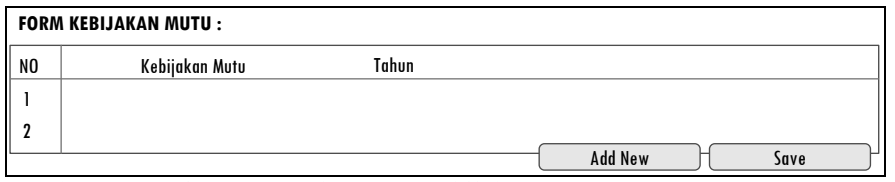

Gambar 7. Desain Antar muka Form Kebijakan Mutu

Penjelasan antar muka Gambar 7 dapat dilihat pada Tabel 4 terkait nama komponen, Tujuan / Deskripsi, Tipe dan Editable [13].

TABEL IV. DESKRIPSI KOMPONEN PADA FORM KEBIJAKAN MUTU

\begin{tabular}{|l|l|l|l|l|}
\hline No & $\begin{array}{c}\text { Nama } \\
\text { Komponen }\end{array}$ & \multicolumn{1}{c|}{$\begin{array}{c}\text { Tujuan / } \\
\text { Deskripsi }\end{array}$} & Tipe & $\begin{array}{c}\text { Edita } \\
\text { ble }\end{array}$ \\
\hline 1 & $\begin{array}{l}\text { Kebijakan } \\
\text { Mutu }\end{array}$ & $\begin{array}{l}\text { Mempermudah pengguna dalam } \\
\text { menyimpan data kebijakan mutu } \\
\text { yang ditetapkan oleh } \\
\text { perusahaan. Jumlah kebijakan } \\
\text { mutu yang disimpan bisa lebih } \\
\text { dari satu data. }\end{array}$ & $\begin{array}{l}\text { Tombol, } \\
\text { textfield, } \\
\text { gridview }\end{array}$ & Ya \\
\hline 2 & Tahun & $\begin{array}{l}\text { Mempermudah pengguna dalam } \\
\text { menyimpan data tahun dari } \\
\text { kebijakan mutu yang ditetapkan } \\
\text { oleh perusahaan. Jumlah tahun } \\
\text { yang disimpan sesuai dengan } \\
\text { jumlah kebijakan mutu. }\end{array}$ & $\begin{array}{l}\text { Tombol, } \\
\text { textfield, } \\
\text { gridview }\end{array}$ & Ya \\
\hline
\end{tabular}

Gambar 8 adalah desain antar muka yang terkait dengan klausul 6.2.1 dimana sasaran mutu dicatat sebagai informasi terdokumentasi.

\begin{tabular}{l} 
FORM SASARAN MUTU \\
\begin{tabular}{|l|c|c|c|c|c|c|c|}
\hline No & Sasaran Mutu & Sumber daya & PIC & Waktu & Rekaman & Target & Action Plan \\
\hline 1 & Sasaran Mutu 1 & & & & & & \\
\hline
\end{tabular} \\
\hline
\end{tabular}

Gambar 8. Desain Antar muka Form Sasaran Mutu

Penjelasan antar muka Gambar 8 dapat dilihat pada Tabel 5 terkait nama komponen, tujuan / deskripsi, tipe dan editable [13].

TABEL V. DESKRIPSI KOMPONEN PADA FORM SASARAN MUTU

\begin{tabular}{|l|l|l|l|c|}
\hline No & $\begin{array}{c}\text { Nama } \\
\text { Komponen }\end{array}$ & \multicolumn{1}{|c|}{$\begin{array}{c}\text { Tujuan / } \\
\text { Deskripsi }\end{array}$} & Tipe & $\begin{array}{c}\text { Edita } \\
\text { ble }\end{array}$ \\
\hline 1 & $\begin{array}{l}\text { Sasaran } \\
\text { Mutu }\end{array}$ & $\begin{array}{l}\text { Mempermudah pengguna } \\
\text { dalam menyimpan sasaran } \\
\text { mutu yang ditetapkan oleh } \\
\text { perusahaan. Jumlah sasaran } \\
\text { mutu dapat lebih dari satu } \\
\text { data }\end{array}$ & $\begin{array}{l}\text { Tombol, } \\
\text { textfield, } \\
\text { gridview }\end{array}$ & Ya \\
& $\begin{array}{l}\text { Mempermudah pengguna } \\
\text { dalam menyimpan sumber }\end{array}$ & $\begin{array}{l}\text { Tombol, } \\
\text { textfield, }\end{array}$ & Ya \\
\hline 2 & $\begin{array}{l}\text { Sumber } \\
\text { daya }\end{array}$ & \multicolumn{2}{|l}{} & \\
\hline
\end{tabular}




\begin{tabular}{|c|c|c|c|c|}
\hline No & $\begin{array}{c}\text { Nama } \\
\text { Komponen }\end{array}$ & $\begin{array}{c}\text { Tujuan / } \\
\text { Deskripsi }\end{array}$ & Tipe & $\begin{array}{c}\text { Edita } \\
\text { ble }\end{array}$ \\
\hline & & $\begin{array}{l}\text { daya yang dibutuhkan untuk } \\
\text { mencapai sasaran mutu }\end{array}$ & gridview & \\
\hline 3 & PIC & $\begin{array}{l}\text { Mempermudah pengguna } \\
\text { dalam menyimpan orang yang } \\
\text { bertanggung jawab terhadap } \\
\text { sasaran mutu }\end{array}$ & $\begin{array}{l}\text { Tombol, } \\
\text { textfield, } \\
\text { gridview }\end{array}$ & Ya \\
\hline 4 & Waktu & $\begin{array}{lr}\text { Mempermudah } & \text { pengguna } \\
\text { dalam menyimpan } & \text { frekuensi } \\
\text { evaluasi terhadap sasaran } \\
\text { mutu }\end{array}$ & $\begin{array}{l}\text { Tombol, } \\
\text { textfield, } \\
\text { gridview }\end{array}$ & Ya \\
\hline 5 & Rekaman & $\begin{array}{lr}\text { Mempermudah pengguna } \\
\text { dalam menyimpan rekaman } \\
\text { yang diperlukan untuk } \\
\text { mengetahui sasaran mutu } \\
\text { tercapai atau tidak } & \\
\end{array}$ & $\begin{array}{l}\text { Tombol, } \\
\text { textfield, } \\
\text { gridview }\end{array}$ & Ya \\
\hline 6 & Target & $\begin{array}{l}\text { Mempermudah pengguna } \\
\text { dalam menyimpan target dari } \\
\text { sasaran mutu tersebut }\end{array}$ & $\begin{array}{l}\text { Tombol, } \\
\text { textfield, } \\
\text { gridview }\end{array}$ & Ya \\
\hline 7 & Action Plan & $\begin{array}{l}\text { Mempermudah pengguna } \\
\text { dalam menentukan rencana } \\
\text { langkah - langkah yang } \\
\text { dilakukan untuk mencapai } \\
\text { sasaran mutu }\end{array}$ & $\begin{array}{l}\text { Tombol, } \\
\text { textfield, } \\
\text { gridview }\end{array}$ & Ya \\
\hline
\end{tabular}

Gambar 9 adalah desain antar muka yang terkait dengan klausul 7.1.5 , 7.1.5.1, 7.1.5.2 dan 7.2 dimana sumber daya dicatat sebagai informasi terdokumentasi.

\section{FORM SUMBER DAYA}

Sumber Daya Orang:
\begin{tabular}{|l|c|c|c|c|}
\hline N0 & Bagian & Jumlah & Pekerjaan & Kendala \\
\hline 1 & Produksi & 20 & Operator & \\
\hline 2 & Kepala Produksi & 1 & Kepala & \\
\hline
\end{tabular}

Infrastruktur :

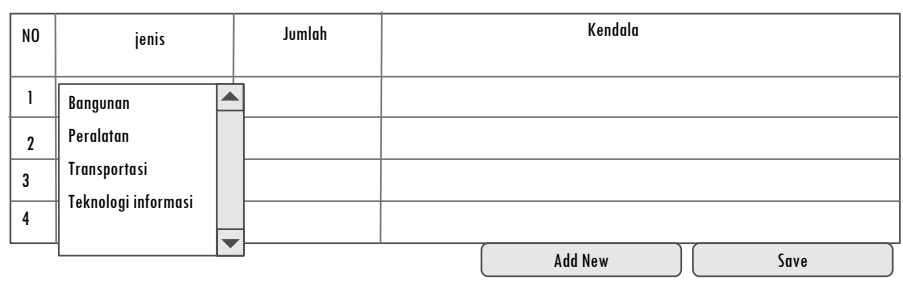

Lingkungan operasi proses:
\begin{tabular}{|c|c|c|c|c|}
\hline N0 & Sumber Daya & Jumlah & & \\
\hline 1 & & sosial & & \\
\hline 2 & & psikologis & & \\
\hline 3 & & fisik & & \\
\hline
\end{tabular}

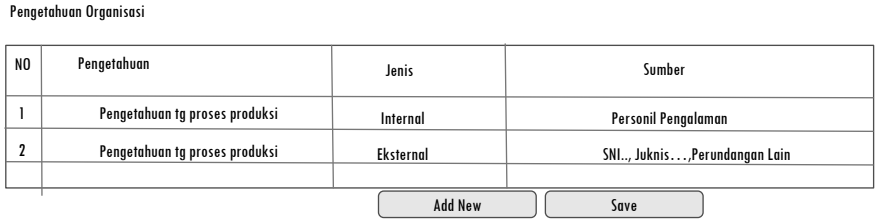

Gambar 9. Desain Antar muka Form Sumber Daya Sistem Manajemen Mutu pada Organisasi

Penjelasan antar muka Gambar 9 dapat dilihat pada Tabel 6 terkait nama komponen, tujuan / deskripsi, tipe dan editable [13].

TABEL VI. DESKRIPSI KOMPONEN PADA FORM SUMBER DAYA

\begin{tabular}{|c|c|c|c|c|}
\hline No & $\begin{array}{c}\text { Nama } \\
\text { Komponen }\end{array}$ & $\begin{array}{c}\text { Tujuan / } \\
\text { Deskripsi }\end{array}$ & Tipe & $\begin{array}{c}\text { Edita } \\
\text { ble }\end{array}$ \\
\hline 1 & $\begin{array}{l}\text { Sumber } \\
\text { Daya Orang }\end{array}$ & $\begin{array}{l}\text { Menyimpan data sumber daya } \\
\text { orang yang dibutuhkan terkait : } \\
\text { bagian, jumlah, jenis pekerjaan } \\
\text { dan kemungkinan kendala yang } \\
\text { dihadapi }\end{array}$ & $\begin{array}{l}\text { Tombol, } \\
\text { textfield, } \\
\text { gridview }\end{array}$ & $\mathrm{Ya}$ \\
\hline 2 & $\begin{array}{l}\text { Sumber } \\
\text { Daya } \\
\text { Infrastruktur }\end{array}$ & $\begin{array}{l}\text { Menyimpan data sumber daya } \\
\text { infrastruktur yang dimiliki } \\
\text { terkait jenis, jumlah dan kendala } \\
\text { yang dihadapi }\end{array}$ & $\begin{array}{l}\text { Tombol, } \\
\text { dropdown } \\
\text { list, } \\
\text { textfield, } \\
\text { gridview }\end{array}$ & $\mathrm{Ya}$ \\
\hline 3 & $\begin{array}{l}\text { Sumber } \\
\text { Daya } \\
\text { Peralatan }\end{array}$ & $\begin{array}{l}\text { Menyimpan data sumber daya } \\
\text { perlaatan yang dibutuhkan } \\
\text { terkait : Nama ALat, Nama Alat, } \\
\text { Jumlah, Tanggal Kalibrasi } \\
\text { Terakhir, Tanggal Kalibrasi } \\
\text { Selanjutnya, No Sertifikat, } \\
\text { Nama Standar Kalibrasi }\end{array}$ & $\begin{array}{l}\text { Tombol, } \\
\text { textfield, } \\
\text { gridview }\end{array}$ & $\mathrm{Ya}$ \\
\hline 4 & $\begin{array}{l}\text { Sumber } \\
\text { Daya } \\
\text { Lingkungan } \\
\text { Operasi } \\
\text { Proses } \\
\end{array}$ & $\begin{array}{l}\text { Menyimpan data sumber daya } \\
\text { lingkungan operasi proses yang } \\
\text { dimiliki terkait : sumber daya } \\
\text { lingkungan, jenis (social, } \\
\text { psikologis, fisik) }\end{array}$ & $\begin{array}{l}\text { Tombol, } \\
\text { dropdown } \\
\text { list, } \\
\text { gridview }\end{array}$ & $\mathrm{Ya}$ \\
\hline 4 & $\begin{array}{l}\text { Sumber Daya } \\
\text { Pengetahuan } \\
\text { Organisasi }\end{array}$ & $\begin{array}{l}\text { Menyimpan } \\
\text { organisasi, jenis pengetahuan } \\
\text { dan sumber pengetauan. }\end{array}$ & $\begin{array}{l}\text { Tombol, } \\
\text { textfield, } \\
\text { gridview }\end{array}$ & $\mathrm{Ya}$ \\
\hline
\end{tabular}

Berikut ini adalah desain antar muka untuk klausul 7.5.2 Membuat dan Memutakhirkan Dokumen SNI ISO 9001:2008. Pada Gambar 10 diperlihatkan form untuk membuat dan merevisi dokumen. 


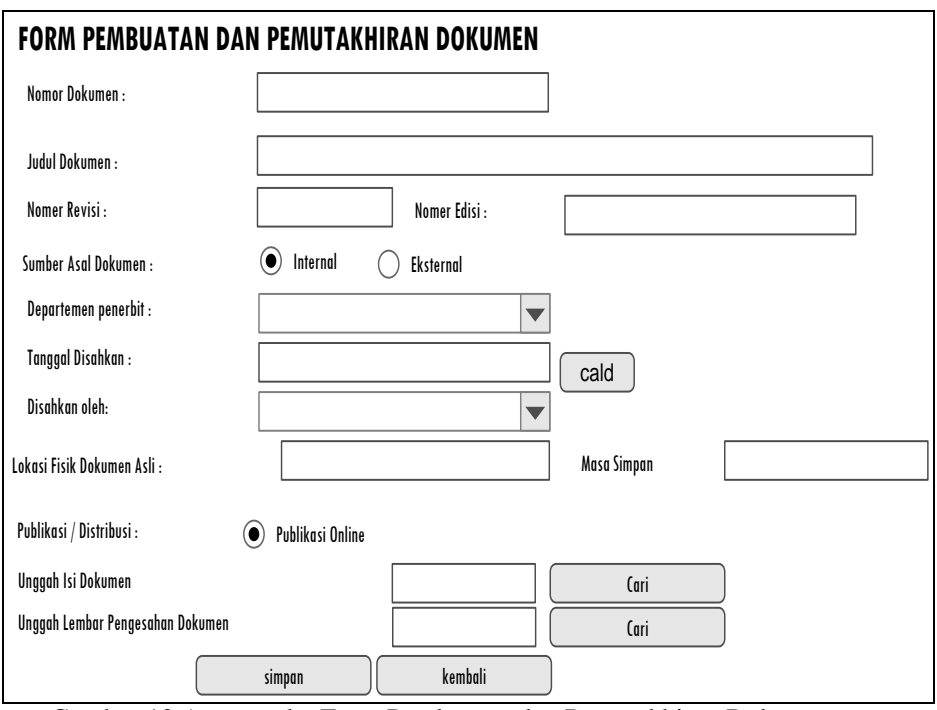

Gambar 10 Antar muka Form Pembuatan dan Pemutakhiran Dokumen

Penjelasan antar muka Gambar 10 dapat dilihat pada Tabel 7 terkait nama komponen, tujuan / deskripsi, tipe dan editable [13].

TABEL VII. DESKRIPSI KOMPONEN PADA FORM PEMBUATAN DAN PEMUTAKHIRAN DOKUMEN

\begin{tabular}{|c|c|c|c|c|}
\hline No & $\begin{array}{c}\text { Nama } \\
\text { Komponen }\end{array}$ & $\begin{array}{c}\text { Tujuan / } \\
\text { Deskripsi }\end{array}$ & Tipe & $\begin{array}{l}\text { Edit } \\
\text { able }\end{array}$ \\
\hline 1 & $\begin{array}{l}\text { Nomor } \\
\text { Dokumen }\end{array}$ & $\begin{array}{l}\text { Mempermudah pengguna dalam } \\
\text { menyimpan nomer dokumen }\end{array}$ & textfield & Ya \\
\hline 2 & $\begin{array}{l}\text { Judul } \\
\text { dokumen }\end{array}$ & $\begin{array}{l}\text { Mempermudah pengguna dalam } \\
\text { menyimpan judul dokumen }\end{array}$ & textfield & Ya \\
\hline 3 & $\begin{array}{l}\text { Nomor } \\
\text { Revisi }\end{array}$ & $\begin{array}{lll}\begin{array}{l}\text { Mempermudah } \\
\text { menyimpan }\end{array} & \text { nomer } & \text { revisi } \\
\text { dokumen } & & \\
\end{array}$ & textfield & ya \\
\hline 4 & Nomer Edisi & $\begin{array}{l}\text { Mempermudah pengguna dalam } \\
\text { menyimpan nomer edisi } \\
\text { dokumen }\end{array}$ & textfield & ya \\
\hline 5 & $\begin{array}{l}\text { Sumber Asal } \\
\text { Dokumen }\end{array}$ & $\begin{array}{l}\text { Mempermudah pengguna dalam } \\
\text { menyimpan asal dokumen } \\
\text { apakah dok internal atau } \\
\text { eksternal }\end{array}$ & $\begin{array}{l}\text { Radio } \\
\text { button }\end{array}$ & ya \\
\hline 6 & $\begin{array}{l}\text { Departemen } \\
\text { Penerbit }\end{array}$ & $\begin{array}{l}\text { Mempermudah pengguna dalam } \\
\text { menyimpan departemen / bagian } \\
\text { yang menerbitkan dokumen }\end{array}$ & $\begin{array}{l}\text { Drop down } \\
\text { list }\end{array}$ & \\
\hline 7 & $\begin{array}{l}\text { Tanggal } \\
\text { Disahkan }\end{array}$ & $\begin{array}{l}\text { Mempermudah pengguna dalam } \\
\text { memilih dan menyimpan tanggal } \\
\text { penerbitan dokumen }\end{array}$ & $\begin{array}{l}\text { Button } \\
\text { kalender }\end{array}$ & ya \\
\hline 8 & Disahkan oleh & $\begin{array}{l}\text { Mempermudah pengguna dalam } \\
\text { menyimpan nama pegawai dan } \\
\text { jabatannya }\end{array}$ & $\begin{array}{l}\text { Drop down } \\
\text { list }\end{array}$ & ya \\
\hline 9 & $\begin{array}{lr}\text { Lokasi } & \text { Fisik } \\
\text { Dokumen } & \text { Asli }\end{array}$ & $\begin{array}{l}\text { Mempermudah pengguna dalam } \\
\text { menyimpan lokasi fisik dari } \\
\text { dokumen }\end{array}$ & textfield & ya \\
\hline 10 & Masa Simpan & $\begin{array}{l}\text { Mempermudah pengguna dalam } \\
\text { menyimpan masa simpan } \\
\text { dokumen sehingga nantinya } \\
\text { dapat digunakan alert jika }\end{array}$ & textfield & ya \\
\hline
\end{tabular}

\begin{tabular}{|c|c|c|c|c|}
\hline No & $\begin{array}{c}\text { Nama } \\
\text { Komponen }\end{array}$ & $\begin{array}{c}\text { Tujuan / } \\
\text { Deskripsi }\end{array}$ & Tipe & $\begin{array}{l}\text { Edit } \\
\text { able }\end{array}$ \\
\hline & & mencapai masa simpan & & \\
\hline 11 & $\begin{array}{l}\text { Publikasi } \\
\text { Distribusi }\end{array}$ & $\begin{array}{l}\text { Semua dokumen didistribusi } \\
\text { secara online }\end{array}$ & $\begin{array}{l}\text { Radio } \\
\text { button read } \\
\text { only }\end{array}$ & tidak \\
\hline 12 & $\begin{array}{l}\text { Unggah } \\
\text { Dokumen }\end{array}$ & $\begin{array}{l}\text { Mempermudah pengguna dalam } \\
\text { mengunggah isi dokumen }\end{array}$ & $\begin{array}{l}\text { Tombol } \\
\text { cari dan } \\
\text { textfield }\end{array}$ & yа \\
\hline 13 & $\begin{array}{l}\text { Unggah } \\
\text { Lembar } \\
\text { Pengesahan }\end{array}$ & $\begin{array}{l}\text { Mempermudah pengguna dalam } \\
\text { menyimpan lembar pengesahan } \\
\text { dokumen }\end{array}$ & $\begin{array}{l}\text { Tombol } \\
\text { cari dan } \\
\text { textfield }\end{array}$ & yа \\
\hline
\end{tabular}

Pada Gambar 11 diperlihatkan antar muka untuk 7.5.3 khususnya mengenai distribusi dokumen.

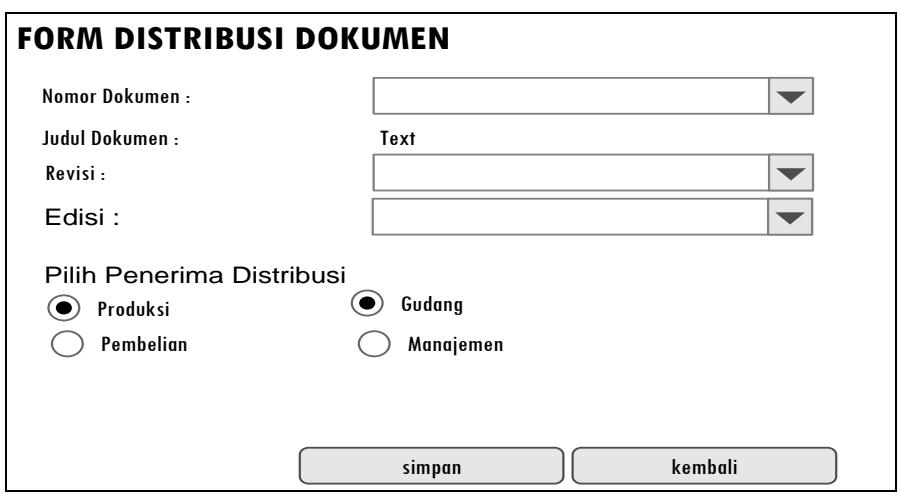

Gambar 11 Antar muka Form Distribusi Dokumen

Penjelasan antar muka Gambar 11 dapat dilihat pada Tabel 8 terkait nama komponen, tujuan / deskripsi, tipe dan editable [13].

TABEL VIII. DESKRIPSI KOMPONEN PADA FORM DISTRIBUSI DOKUMEN

\begin{tabular}{|l|l|l|l|l|}
\hline No & \multicolumn{1}{|c|}{$\begin{array}{c}\text { Nama } \\
\text { Komponen }\end{array}$} & \multicolumn{1}{c|}{$\begin{array}{c}\text { Tujuan / } \\
\text { Deskripsi }\end{array}$} & $\begin{array}{c}\text { Tipe } \\
\text { ble }\end{array}$ \\
\hline 1 & $\begin{array}{l}\text { Nomor } \\
\text { Dokumen }\end{array}$ & $\begin{array}{l}\text { Mempermudah pengguna } \\
\text { dalam memilih dokumen yang } \\
\text { harus didistribusikan }\end{array}$ & textfield & ya \\
\hline 2 & $\begin{array}{l}\text { Judul } \\
\text { Dokumen }\end{array}$ & $\begin{array}{l}\text { Menampilkan judul dokumen } \\
\text { yang dipilih }\end{array}$ & label & tdk \\
\hline 3 & $\begin{array}{l}\text { Revisi } \\
\text { Dokumen }\end{array}$ & $\begin{array}{l}\text { Mempermudah pengguna } \\
\text { dalam memilih revisi dokumen } \\
\text { yang harus didistribusikan }\end{array}$ & $\begin{array}{l}\text { Drop down } \\
\text { list }\end{array}$ & ya \\
\hline 4 & $\begin{array}{l}\text { Edisi } \\
\text { Dokumen }\end{array}$ & $\begin{array}{l}\text { Mempermudah pengguna } \\
\text { dalam memilih edisi dokumen } \\
\text { yang harus disitribusikan }\end{array}$ & $\begin{array}{l}\text { Drop down } \\
\text { list }\end{array}$ & ya \\
\hline 4 & Pilih Penerima & $\begin{array}{l}\text { Mempermudah pengguna } \\
\text { dalam memilih bagian atau } \\
\text { penerima distribusi dokumen }\end{array}$ & $\begin{array}{l}\text { Radio } \\
\text { button }\end{array}$ & ya \\
\hline
\end{tabular}




\section{KESIMPULAN}

Rancangan arsitektur sistem telah didapatkan untuk mempermudah perusahaan kecil dimana tidak memerlukan investasi software karena aplikasi dalam penelitian ini disediakan untuk dapat diakses melalui koneksi internet dengan penggunan login untuk hak akses yang berbeda setiap perusahaan pengguna sehingga menjamin keamanan data.

Rancangan Antar muka untuk klausul 4 sampai dengan klausul 7 ISO 9001:2015 telah didapatkan, dimana diperlukan 6 form untuk dapat menyimpan informasi terdokumentasi yang diperlukan yaitu Form Lingkup Manajemen Mutu, Form Proses yang Diperlukan Sistem Manajemen Mutu, Form Kebijakan Mutu, Form Sasaran Mutu, Form Sumber Daya, Form Pembuatan dan Pemutakhiran Dokumen dan Form Distribusi Dokumen.

Rancangan fitur-fitur komponen diharapkan dapat mempermudah user dalam mengelola informasi terdokumentasi SNI ISO 9001:2015 perusahaannya khususnya klausul 4 s.d klausul 7.

Untuk penelitian selanjutnya sebaiknya dilakukan ujicoba sistem pada perusahaan manufaktur yang sudah bersertifikasi SNI ISO 9001:2015 guna mendapatkan masukan implementasi.

\section{DAFTAR PUSTAKA}

[1] Van Der Spiegel, M. Measuring Effectiveness of Food Quality Management System. PhD Thesis,Wageningen University, Netherlands, 2004

[2] Harrigan,W.F. The IS0 9000 series and its implications for HACCP. Food Control 1993; 4(2): 105-111

[3] ISO. ISO 9001, Quality Management System-Requirements. Geneva: ISO; 2008.
[4] van den Heuvel, J., Koning, L., Bogers, Ad J. J. C., Berg, M., and van Dijen, M. E. M. An ISO 9001 Quality Management System in A Hospital, Bureaucracy or Just benefits?. International Journal of HealthCare Quality Assurance 2005; 18(5): 361-369.

[5] Psomas, E.L., Kafetzopoulos, D.P. and Fotopoulos, C.V. Developing and validating a measurement instrument of ISO 9001 effectiveness in food manufacturing SMEs. Journal of Manufacturing Technology Management 2013; 24(1): 52-77

[6] Lewis,W.G., Pun, K.F., and Lalla, T.R.M. An Empirical Analysis of ISO 9004:2000 Maturity in ISO 9001 Certified SMEs. The Asian Journal on Quality 2006; 6(3): 190-203

[7] Fotopoulos, C.V., Psomas, E.L., and Vouzas, F.K. ISO 9001:2000 implementation in the Greek food sector. The TQM Journal 2010; 22(2): $129-142$

[8] J. G. Sanz-Calcedo et al, , Analysis on integrated management of the quality, environment and safety on the industrial projects, The Manufacturing Engineering Society International Conference, MESIC 2015, Procedia Engineering 132 ( 2015 ) 140 - 145

[9] Liviu Dorin Pop, Study on creating a simplified Model of Quality Management System in a SME from the central region of Romania, $9^{\text {th }}$ international conference interdisciplinary in Engineering, INTER-ENG 2015, 8-9 october 2015, Tirgu-Mures, Romania, Procedia Technology 22 (2016) 1084 - 1091

[10] José Manuel Conde Hernada, Methodology for implementing Document Management Systems to support ISO 9001:2008 Quality Management Systems, The Manufacturing Engineering Society International Conference, MESIC 2013, Procedia Engineering 63 ( 2013 ) 29 - 35

[11] Hong Jin Jeong et al, Development of Hybrid Quality Management System for Construction Equipment Part Industry, 27th International Conference on Flexible Automation and Intelligent Manufacturing, FAIM2017, 27-30 June 2017, Modena, Italy, Procedia Manufacturing 11 ( 2017 ) $2139-2146$

[12] Helgi Thor Ingason, Best Project Management Practices in the Implementation of an ISO 9001 Quality Management System, 28th IPMA World Congress, IPMA 2014, 29 September - 1 October 2014 Rotterdam, The Netherlands, Procedia - Social and Behavioral Sciences 194 ( 2015 ) $192-200$

[13] Lobaziewicz Monika, The design of B2B system user interface for mobile systems, International Conference on Communication, Management and Information Technology (ICCMIT 2015) 